Indonesian Journal of Biotechnology, June, 2015

Vol. 20, No. 1, pp.69-76

\title{
Black Rice Bran Extracts and Fractions Containing Cyanidin 3-glucoside and Peonidin 3-glucoside Induce Apoptosis in Human Cervical Cancer Cells
}

\author{
Rarastoeti Pratiwi ${ }^{1 *}$, Woro Anindito Sri Tunjung ${ }^{1}$, Rumiyati $^{2}$ and Alfi Rizqi Amalia ${ }^{3}$ \\ ${ }^{1}$ Laboratory of Biochemistry, Faculty of Biology, Universitas Gadjah Mada, Yogyakarta, Indonesia, \\ 55281 \\ ${ }^{2}$ Laboratory of Biochemistry, Faculty of Pharmacy, Universitas Gadjah Mada, Yogyakarta, Indonesia, \\ 55281 \\ ${ }^{3}$ Master Student of Graduate Program of Faculty of Biology, Universitas Gadjah Mada, Yogyakarta, \\ Indonesia, 55281
}

\begin{abstract}
Anthocyanin of pigmented rice inhibits the growth of cancer cells. The cytotoxicity and apoptosisinducing properties of local black rice (cv Cempo Ireng) extracts and fractions, which contain anthocyanin including cyanidin 3-glucoside and peonidin 3-glucoside, on human cervical cancer cell line (HeLa cells) has been evaluated. The pigmented rice bran was extracted and fractionated using methanol-HCl. The MTT test was performed on HeLa cell cultures to observe the $\mathrm{IC}_{50}$ value. Preparative TLC was performed to obtain the fractions of black rice bran. Cyanidin 3-glucoside and peonidin 3-glucoside were identified in the pigmented rice bran extract and fractions using UHPLC. Flowcytometry analysis was performed to measure the percentage of apoptotic cells. Our results suggest that the fractions are more toxic than the methanolic crude extract with $\mathrm{IC}_{50}$ values of $85.95 \pm 5.56 \mu \mathrm{g} / \mathrm{mL}$ (the lowest one) and $408.13 \pm 51.9 \mu \mathrm{g} / \mathrm{mL}$, respectively. The concentration of cyanidin 3-glucoside and peonidin 3-glucoside in the methanolic extract were 1.89 and $0.84 \mu \mathrm{g} / \mathrm{mg}$, respectively. The apoptosis induction by fractions F2 and F4 (52 and 55\%) were significantly higher compared to fraction F3 and F5 (30 and 33\%) and doxorubicin (21\%). Cyanidin 3-glucoside was detected in F4 $(0.14 \mu \mathrm{g} / \mathrm{ml})$ while peonidin 3-glucoside in F2 $(0.012 \mu \mathrm{g} / \mathrm{ml})$, however both were not detected in F3 and F5.
\end{abstract}

Keywords: Cempo Ireng, cyanidine 3-glucoside, peonidin 3-glucoside, apoptosis, HeLa cells

\section{Introduction}

Indonesia is rich in terms of biodiversity, containing many local black rice cultivars. One of them is cultivated in the Special Region of Yogyakarta Province (DIY) named as 'Cempo Ireng' (Kristamtini et al., 2013). Previous studies reported that Cempo Ireng contains high level of anthocyanin and antioxidant activity, thus normalize serum lipid profile in hyperlipidemia rats (Kristamtini et al., 2012; Pratiwi et al., 2014).

*Corresponding author:

Laboratory of Biochemistry, Faculty of Biology, Universitas Gadjah Mada

Jl. Teknika Selatan, Sekip Utara Yogyakarta 55281

E-mail: rarastp@ugm.ac.id, rarastp@yahoo.com
Deng et al., (2013) and Banjerdpongchai et al., (2013) reported that black rice or pigmented rice contains variety of flavones; including anthocyanins, tannin, polyphenols, sterols, tocopherols, $\gamma$-oryzanols, amino acids, and essential oils which are mostly concentrated in the rice bran. Varieties of the pigmented rice are distributed in many countries such as India (Mohanlal et al., 2011), China (Xia et al., 2006), Thailand (Banjerdpongchai et al., 2013), Japan (Tanaka et al., 2008; Matsuba et al., 2010).), Korea (Kim et al., 2008; Lee, 2010) and Indonesia (Suliartini et al., 2011; Kristamtini et al., 2012). The bio-activity of phytochemical compounds in the pigmented rice has been shown as potential cure to metabolic diseases and trigger apoptosis in cancer cells (Deng et al., 2013). 
The aleurone layer of black rice contains $43.2 \%$ of total anthocyanin, mostly consists of cyanidin 3-glucoside and peonidin 3-glucoside which posses antioxidative activity in chemical and biological model system (Hu et al., 2003; Xia et al., 2006). Cyanidin 3-glucoside and peonidin 3-glucoside also inhibit tumor cell growth both in vitro and in vivo. These compounds may exert cell growth inhibition through an arrest of the G2/M phase of the cell cycle, inhibition of cell proliferation, or induction of apoptosis. So far, these two compounds of anthocyanins have been observed can enhance the inhibitory effect of doxorubicin on cell growth of HS578T cells (human breast carcinoma) and promoted to be a potential candidate for cancer chemoprevention (Chen et al., 2005). Hyun and Chung (2004) also reported that anthocyanins isolated from $\mathrm{O}$. sativa cv Heugjinjubyeo showed cytotoxicity through the arrest of G2/M phase of the cell cycle and induction of apoptosis in monocytic leukemia cells. Furthermore, the inhibitory effect of cell invasion on various cancer cells, including HeLa cells, by these compounds was also reported previously (Chena et al., 2006).

This study aims to evaluate the apoptotic activity of local black rice bran (Oryza sativa L. Indica var cv Cempo Ireng) extract and fractions on human cervical cancer cells (HeLa cells).

\section{Materials and Methods \\ Chemicals and cell lines}

Methanol, $\mathrm{HCl}$, n-heksan, n-butanol, glacial acetic acid, silica gel powder $60 \mathrm{~F}_{254}$ were obtained from Merck. Tripsin, MTT [3-(4,5-dimethyl)-2,5-diphenyl tetrazolium bromide], penicillin-streptomycin, fetal bovine serum (FBS), fungizone and RPMI medium were obtained from Gibco. Phosphate Buffer Saline (PBS) was obtained from Sigma, whereas dimethylsulfoxide (DMSO) from Merck and doxorubicin from Ebewe. Human cervical cancer cells (HeLa) were obtained from a culture collection of the Laboratory of Parasitology, Faculty of Medicine, Universitas Gadjah Mada (UGM).

\section{Rice materials and extraction}

Black rice (Oryza sativa L. Indica) cv Cempo Ireng was planted and collected from rice farmer Mr. Jamasto from Sayegan, Sleman DIY in 2014. Black rice bran extraction was performed by modifying Kim et al. (2008) which has been modified by AbdelAal et al. (2006). The rice bran (100g) was macerated using $1 \mathrm{~L}$ of methanol, whereas BRB was also extracted with water as a solvent using a procedure that modified from Tan et al. (2013): HCL 1 N (85:15) for 48 hours, while being stirred occasionally to prevent saturation. After being rested for 2 nights, the bran mass was filtered using Whatman No. 1 filter. The maceration process was repeated twice, with 24 hours of resting period between each process. The methanolic extract was evaporated using waterbath at $60^{\circ} \mathrm{C}$ to obtain the dry extract.

The dry extract was dissolved in 5\% of the media (2.5\% DMSO and $97.5 \%$ of RPMI) as a stock solution. Cells were treated with extract at the concentrations of 2000, 1000, 500,250 , and $125 \mu \mathrm{g} / \mathrm{mL}$ and the maximal DMSO concentration in each well was $0.2 \%$, followed by $48 \mathrm{~h}$ incubation.

\section{Cell culture}

Propagation of HeLa cells was conducted by the following procedures established by the Laboratory of Parasitology, Faculty of Medicine UGM. Human cervical cancer HeLa cells were cultured in RPMI medium containing $2 \%$ penicillin-streptomycin, $0.5 \%$ of fungizone and $10 \%$ FBS. The methanolic extract, in the form of dry powder, was dissolved in dimethyl sulfoxide (DMSO) as a vehicle with a maximal volume of $10 \mu \mathrm{l} /$ $\mathrm{mL}$ media. The cell were grown at $37^{\circ} \mathrm{C}$ in a $5 \% \mathrm{CO}_{2}$ atmosphere. The cells $\left(5 \times 10^{3}\right)$ were treated with methanolic extracts of rice bran at indicated concentrations and durations. 


\section{Cytotoxic test by MTT assay}

Cytotoxic test was conducted by modifying Nurhayati et al. (2015). One hundred $\mu \mathrm{L}$ of human cervical cancer $(\mathrm{HeLa}$ cells) suspension with a density of $5 \times 10^{3} / 100$ $\mu \mathrm{L}$ media was distributed into 96-well plate and incubated for 24 hours. After incubation, $100 \mu \mathrm{L}$ of rice bran methanolic extract in different concentrations was added into the well. As a control, $100 \mu \mathrm{L}$ of doxorubicin in different concentration was used, and $100 \mu \mathrm{L}$ of culture medium was left without treatment. The cells were incubated for 48 hours in the incubator with $5 \% \mathrm{CO}_{2}$ and $95 \% \mathrm{O}_{2}$ flows. At the end of incubation, culture media were removed and $110 \mu \mathrm{L}$ of MTT solution $(5 \mathrm{mg}$ / mL PBS) was added, followed by 3-4 hours incubation. MTT reaction was stopped by adding stopper reagent SDS $(100 \mu \mathrm{L})$.

Cell-containing micro-plate was sealed for \pm 5 minutes, wrapped with aluminum foil and incubated for overnight at room temperature. The assay results were analyzed using an ELISA reader at $595 \mathrm{~nm}$ wavelength. The cell death percentage was calculated based on the formula $[\{(\mathrm{A}-\mathrm{D})-(\mathrm{B}-\mathrm{C})\} /(\mathrm{A}-\mathrm{D})]$ $\mathrm{X} 100 \%$, in which $\mathrm{A}=$ control absorbance, $\mathrm{b}=$ extract absorbance, $\mathrm{C}=$ extract control absorbance, and $\mathrm{D}=$ media control absorbance. The value of Inhibitor Concentration $50\left(\mathrm{IC}_{50}\right)$ was determined statistically using probit analysis with SPSS 13 statistic application.

\section{Fractionation of black rice bran methanolic extract}

The methanolic extract of black rice bran (1g crude extract homogenized in $3 \mathrm{~mL}$ methanol) was fractionated and isolated using preparative-thin layer chromatography with silica-gel as stationery-phase and buthanol as mobile phase. The solvents are buthanol : acetic acid: water (4:1:5 v/v) after being concentrated for 17 hours. The extract was dotted on the silica plate using capillary pipe at about $1.5 \mathrm{~cm}$ from the bottom. The silica plate was put in the solvent jar and incubated for 3 hours (when the eluen reached about $1.5 \mathrm{~cm}$ from the upper edge). Bands on the plate were exposed to UV
254 and UV $366 \mathrm{~nm}$. The bands were marked on the Rf side and scraped carefully. The fractions were macerated using methanol: $\mathrm{HCl}$ $1 \%$ to eliminate the silica powder. Each fraction was filtered and dried up using waterbath at $60{ }^{\circ} \mathrm{C}$.

\section{Cytotoxicity test of fractions}

Each fraction was tested for the cytotoxic activity on HeLa cells using MTT method with dosage $>\mathrm{IC}_{50}$ of black rice bran methanolic extract.

\section{Apoptosis Analysis Using Flow cytometry}

Apoptosis analysis was performed using flowcytometry using anexin V-FLUOS staining kit. HeLa cells were treated using active fractions of the black rice methanolic extract and doxorubicin for 48 hours. The cells were harvested using $0.25 \%$ trypsin and washed with PBS. The cells were treated using $100 \mu \mathrm{L}$ of Annexin-VFLUOUS staining kit, and incubated in dark condition for 10 minutes at $25^{0}-27^{\circ} \mathrm{C}$. The obtained data of apoptotic and necrotic cells were analyzed using flowcytometer FACSCalybur (BectonDickinson).

\section{Quantification of cyanidine 3-glucoside and peonidin 3-glucoside}

The concentration of cyanidin 3-glucoside and peonidine 3-glucoside in the fractions were detected and measured by using Ultra High Performance Liquid Chromatography (UHPLC-Perkin Elmer, Photo Diode Array or PDA detector and column C-18). The separation process was performed using linear proportion starting from 13\% B to $24 \%$ B for 8 minutes and increased by $100 \%$ in 14 minutes with flow velocity of $0.3 \mathrm{ml} /$ minute. The mobile phase consists of formic acid of 3\% in the Mili-Q water (A) and $\mathrm{Me}-\mathrm{OH}$ UHPLC grade (B). The chromatogram was recorded at an absorbance of $520 \mathrm{~nm}$. Injection volume was $20 \mu \mathrm{l}$ of cyanidin 3-O-glucoside and peonidin 3-O-glucoside. Quantification was performed by calibration of the standard curve and repeated for 3 times. 


\section{Statistical analysis}

Results are expressed as mean \pm SD Statistical differences between control and samples were determined by one-way ANOVA (Kruskal Wallis analysis) at the limit of $p<0.05$ from 3 independent experiments conducted in triplicate. For comparison between two groups, data were analyzed using Mann-Whitney U test.

\section{Results and Discussion}

Methanol is a polar solvent suitable to extract phenolic compound such as flavonoid from the black rice bran, especially anthocyanines including cyanidin 3-glucoside and peonidin 3-glicoside. Water, which is also a polar solvent, possesses different polarity with methanol, thus comparing both solvents to extract the active compounds of black rice bran is of interest. The rendement productions from methanol and water

Table 1. Rendement and colour of black rice 'Cempo Ireng' bran extract

\begin{tabular}{ccl}
\hline Solvent & $\begin{array}{c}\text { Rendement } \\
(\%)\end{array}$ & \multicolumn{1}{c}{$\begin{array}{c}\text { Colour of } \\
\text { extract }\end{array}$} \\
\hline Methanol & 20.60 & Dark red \\
Water & 28.47 & Dark brown \\
\hline
\end{tabular}

extraction process and colour of black rice bran extracts is shown in Table 1.

Methanolic and water extract of black rice bran showed different colours, indicating that each extract contains different portions of pigmented compounds. Anthocyanin is soluble in water, while some pigmentedlipid compounds such as vitamin $\mathrm{E}$ are not soluble.

\section{TLC-Chromatogram of methanolic and water extract of black rice bran}

Chromatogram-TLC profiles of methanolic and water extracts of black rice bran showed 6 and 5 spots of compounds respectively (Table 2). Each extract showed different patterns, except for Rf 0.14 which is similar. Methanolic extract at Rf 0.75 or spot no 5 , showed a clear spot which is similar to rutin (flavanoids standards), suggesting that the anthocyanin compounds, such as

Table 2. Spots and Retardation factor (Rf) on TLC of black rice bran extracts

\begin{tabular}{lcl}
\hline \multicolumn{1}{c}{ Extract } & No. of spots & \multicolumn{1}{c}{ Rf } \\
\hline \multirow{2}{*}{ Methanol } & 6 & $0.14,0.28,0.46,0.62,0.75$, \\
Water & 5 & 0.88 \\
\end{tabular}

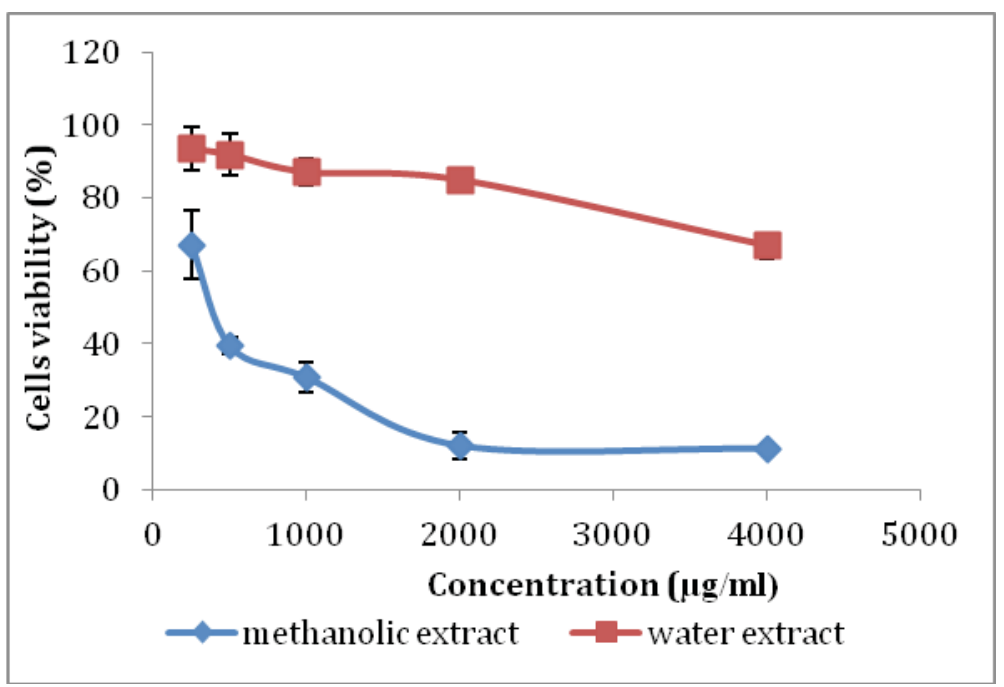

Figure 1. HeLa cells treated with fractions of methanolic and water extract of black rice bran. The cells viability shows decreasing in HeLa cells cultures after treated with methanolic extract compare to water extract treatment. 

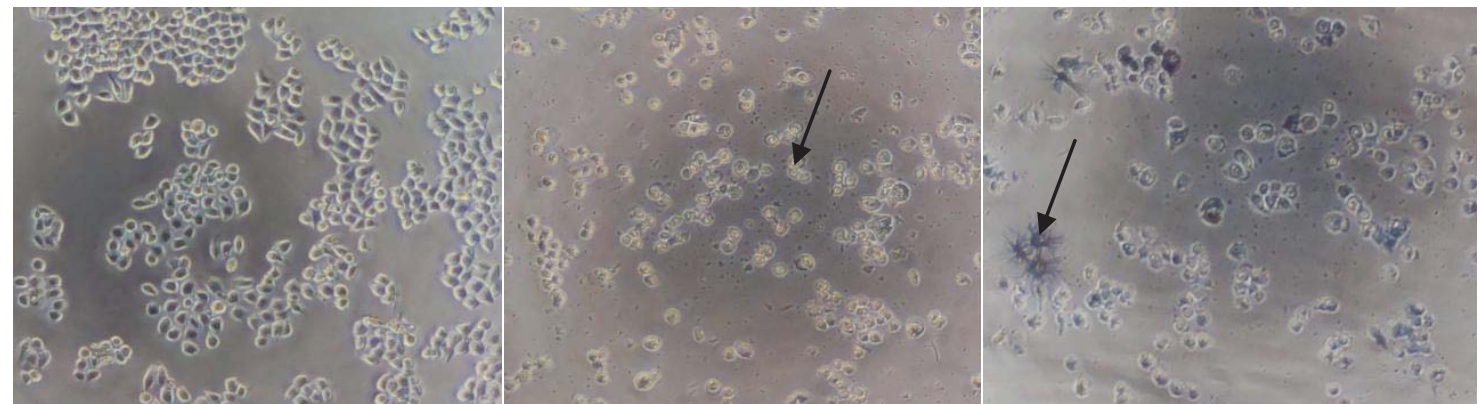

Figure 2. HeLa cells morphology in control media (a), methanolic extract treatment media (b) and $4 \mathrm{~h}$ incubated in MTT media. The death cells are pointed by the arrow.

cyanidin and peonidin, of black rice extract most likely are contained in this spot.

\section{Cytotoxic activity of methanol extract of black rice bran}

Methanolic and water extracts of black rice bran were evaluated for cytotoxicity activities on HeLa cells. Methanolic and water extracts of black rice bran showed different responses on HeLa cells. The Table 3 and Figure 1 showed that the methanolic extract has $\mathrm{IC}_{50}$ of $408.13 \mu \mathrm{g} / \mathrm{mL}$, which is much lower than the water extract. This result might be due to the difference in compounds contained in both extracts. The water extract of black rice bran was not toxic, suggesting that the concentration of cytotoxic compound $\left(\mathrm{IC}_{50}\right.$ value) on cells should be less than $1000 \mu \mathrm{g} / \mathrm{mL}$ (Meyer et al., 1982).

Table 3. The $\mathrm{IC}_{50}$ values of black rice bran methanolic extract on HeLa cells ( $48 \mathrm{~h}$ incubation)

\begin{tabular}{lc}
\hline \multicolumn{1}{c}{ Treatment } & $\mathrm{IC}_{50}(\mu \mathrm{g} / \mathrm{ml})$ \\
\hline $\begin{array}{l}\text { Methanolic extract of black } \\
\text { rice bran }\end{array}$ & $408.13 \pm 51.90$ \\
Water extract of bran & $22,735.26 \pm 17,872.15$ \\
Doxorubicin & $0.46 \pm 0.06$ \\
\hline
\end{tabular}

The cytotoxicity tests results of the methanolic and water extracts correlates with the abnormality of HeLa cells morphology after treatment (Figure 2). The active compounds contained in the extract cause abnormal membrane structures and loss of cell adhesion to adjacent cells or extracellular matrix (Lu et al., 2012).

\section{Cytotoxic effect of the extract fractions on HeL a cells}

The methanolic extract fractions of black rice bran can be separated into 6 fractions with Rf values ranged from $0-0.97$ with each specific colour (Table 4). Most fractions from preparative TLC showed the cytotoxic activities on HeLa cells with $\mathrm{IC}_{50}$ values lower than methanolic extract $(408.13 \mu \mathrm{g} /$ $\mathrm{mL}$ (Table 5). HeLa cells are more sensitive to fractions F5, F3, F2 and F4 with the $\mathrm{IC}_{50}$ values of $86,97,97$ and $111 \mu \mathrm{g} / \mathrm{mL}$ respectively, compared to Fraction F1 and F6.

Table 4. Fractions of black rice bran methanolic extract

\begin{tabular}{cccc}
\hline $\begin{array}{c}\text { PTLC } \\
\text { Fraction }\end{array}$ & Rf & Mass $(\mathbf{g})$ & Colour \\
\hline F1 & $0.81-0.97$ & 0.1566 & Dark yellow \\
F2 & $0.75-0.81$ & 0.0902 & Red \\
F3 & $0.53-0.75$ & 0.1881 & Brown \\
F4 & $0.44-0.53$ & 0.3046 & Dark violet \\
F5 & $0.13-0.44$ & 0.5091 & Black \\
F6 & $0-0.13$ & 0.8019 & Dark brown \\
\hline
\end{tabular}

Table 5. The $\mathrm{IC}_{50}$ values of PTLC fractions to HeLa cells after 48 hours incubation

\begin{tabular}{cc}
\hline Fraction & $\mathrm{IC}_{50}(\mu \mathrm{g} / \mathrm{mL})$ \\
\hline F1 & $180.57 \pm 7.86$ \\
F2 & $96.83 \pm 7.78$ \\
F3 & $91.71 \pm 4.49$ \\
F4 & $111.47 \pm 3.29$ \\
F5 & $85.95 \pm 5.56$ \\
F6 & $131 \pm 0.063$ \\
\hline
\end{tabular}


Table 6. Apoptotic and necrotic cells percentage caused by PTLC fractions of black rice bran methanolic extract on HeLa cells

\begin{tabular}{cccc}
\hline \multirow{2}{*}{ Treatments } & \multicolumn{3}{c}{ Cells Percentage (\%) } \\
\cline { 2 - 4 } & Live & Apoptotic cells & Necrotic cells \\
\hline Media control & $87.85 \pm 0.36^{\mathrm{f}}$ & $9.3 \pm 0.68^{\mathrm{a}}$ & $2.86 \pm 0.32^{\mathrm{a}}$ \\
F2 & $33.88 \pm 1.02^{\mathrm{c}}$ & $52,09 \pm 1.30^{\mathrm{d}}$ & $14,03 \pm 0.28^{\mathrm{b}}$ \\
F3 & $49.15 \pm 0.014^{\mathrm{d}}$ & $32.78 \pm 0.41^{\mathrm{c}}$ & $18.08 \pm 0.40^{\mathrm{c}}$ \\
F4 & $29.22 \pm 0.028^{\mathrm{b}}$ & $55.16 \pm 0.19^{\mathrm{d}}$ & $15.63 \pm 0.16^{\mathrm{b}}$ \\
F5 & $51.85 \pm 0.13^{\mathrm{e}}$ & $30.18 \pm 0,59^{\mathrm{c}}$ & $17.97 \pm 0.72^{\mathrm{c}}$ \\
Doxorubicin & $3.85 \pm 0,11^{\mathrm{a}}$ & $21.29 \pm 0.61^{\mathrm{b}}$ & $74.87 \pm 0.71^{\mathrm{d}}$ \\
\hline
\end{tabular}

Table 7. Cyanidin 3-glucoside and peonidin 3-glucoside concentration in the methanolic extract and fractions of black rice bran

\begin{tabular}{lrrrrrr}
\hline \multirow{2}{*}{ Sample } & \multicolumn{3}{c}{ Cyanidin 3-glycoside } & \multicolumn{3}{c}{ Peonidin 3-glycoside } \\
\cline { 2 - 7 } & \multicolumn{1}{c}{ RT $^{*}$} & \multicolumn{1}{c}{ Area } & conc. $(\mu \mathrm{g} / \mathbf{m g})$ & RT $^{*}$ & \multicolumn{1}{c}{ Area } & \multicolumn{1}{c}{ conc. $(\boldsymbol{\mu g} / \mathbf{m g})$} \\
\hline Extract & 12.81 & $660,331.07$ & 1.89 & 13.80 & $393,357.64$ & 0.843 \\
F4 & 12.85 & $65,738.26$ & 0.14 & nd & 0 & 0 \\
F2 & nd & 0 & 0 & 13.89 & $4,050.64$ & 0.012 \\
F5 & nd & 0 & 0 & nd & 0 & 0 \\
\hline
\end{tabular}

$\mathrm{RT}^{*}=$ Retention Time

nd $=$ not detected

Apoptosis induction on HeLa cells by fractions containing cyanidine 3-glucoside and peonidin 3-glucoside

Fractions of the methanolic extract of black rice bran showed higher cytotoxic activities on HeLa cells compared to the methanol crude extract, but lower than doxorubicin, a common drug for cancer chemotherapy. To confirm whether the cause of cell death is due to apoptosis or necrosis, flowcytometry was performed.

The results demonstrated that all fractions of F2, F3, F4 and F5 induced apoptosis more effectively (> 50\%) compared to doxorubicin (21.29\%) (Table 6). Sugimoto et al. (2002) also reported that low-dose of doxorubicin (40 nmol/L) induced $90 \%$ of necrosis and $8 \%$ of apoptosis in Jurkat cells. Furthermore, the percentages of apoptosis induction by fractions F2 and F4 are higher than F3 and F5. These results are consistent with Hui et al. (2010) suggesting that compounds in the black rice bran induced apoptosis rather than necrosis in HeLa cells.

In addition, we measured the concentration of anthocyianin compounds, especially cyanidin 3-glucoside and peonidin 3 -glucoside. Previous studies reported that anthocyanin compounds have cytotoxic activity and induce apoptosis on several lines of cancer cells (Chen et al., 2005). Cyanidin 3 -glucoside $(1.89 \mathrm{ug} / \mathrm{mL})$ and peonidin 3 -glucoside $(0.84 \mathrm{ug} / \mathrm{mL}$ were identified in the methanolic extract of black rice bran, consistent with Xia et al. (2010). Results also showed that fractions F2 contain only peonidin 3-glucoside whereas F4 only contain cyanidin 3-glucoside (Table 7). In contrast, there were no cyanidin and peonidin detected in fraction F5, while F3 was excluded because the $\mathrm{Rf}$ of this fraction was out of the range of Rf flavonoid standard.

Based on these results, we suggest that the apoptosis induction in HeLa cells most probably is caused by cyanidin 3-glucoside and peondin 3-glucoside containing fractions. Cyanidin 3-glucoside was detected in fraction F4 $(0.14 \mu \mathrm{g} / \mathrm{mL})$ and peonidin 3-glucoside in F2 $(0.012 \mu \mathrm{g} / \mathrm{mL})$. However, both compounds were not detected in fraction F3 and F5 of methanolic extract of black rice 'Cempo Ireng' bran. 


\section{Acknowledgement}

We would like to thank The Ministry of Research, Technology and Higher Education of Republic Indonesia for the research funding under the "Hibah Kompetitif 2015". Many thanks to Fajar Sofyantoro for the endless English corrections.

\section{References}

Abdel-Aal, El Sayed, Christoper, J. Y., and Rabalski, I. 2006. Anthocyianin Composition in Black, Blue, Pink, Purple, and Red Cereal Grain. J. Agric. Food Chem. 54: 4696 - 4704.

Banjerdpongchai,R., Wudtiwai, B., Sringarm, K. 2013. The cytotoxic effect of purple rice extracts on human cancer cells related to their active compounds. 13th ASEAN Food Conference, 9-11 September 2013, Singapore Meeting Future Food Demands: Security \& Sustainability

Chen, P-N.,Chu, S-C., Chiou, H-L., Chiang, C-L., Yang, S-F and Hsieh, Y-S. 2005. Cyanidin 3-Glucoside and Peonidin 3-Glucoside Inhibit Tumor Cell Growth and Induce Apoptosis In Vitro and Suppress Tumor Growth In Vivo. Nutrition and Cancer 53 (2) : 232-243.

Chena, P.N, Kuo, W.H.,Chiang, C.L., Chiou H.L., Hsieh, Y.S., Chuc, S.C. 2006. Black rice anthocyanins inhibit cancer cells invasionvia repressions of MMPs and u-PA expression. Chemico-Biological Interactions 163: 218-229.

Deng, G.F., Xu, X.R., Zhang Y., Li, D., Gan R.Y., Li, H.B. 2013. Phenolic Compounds and Bioactivities of Pigmented Rice. Critical Reviews in Food Science and Nutrition, 53:296-306

Hu, C., Zawistowski, J., Ling, W.H., Kitts, D.D. 2003. Black rice (Oryza sativa L.indica) pigmented fraction suppresses both reactive oxygen species andnitric oxide in chemical and biological model systems. J. Agric. Food Chem. 51:5271-7.

Hui C, Bin Y, Xiaoping Y, Loang Y, Chunye C, and Mantian M. 2010. Anticancer Activities of an Anthocyanin-Rich Extract
From Black Rice Against Breast Cancer Cells In Vitro and In Vivo. Nutrition and Cancer, 62(8), 1128-1136

Hyun JW and Chung HS. 2004. Cyanidin and malvidin from Oryza sativacv.

Heugjinjubyeo mediate cytotoxicity against human monocytic leukemia cells by arrest of G2/M phase and induction of apoptosis. J. Agric. Food Chem.: 52:2213-2217.

Kim, M.-K., Kim, H., Koh, K., Kim, H.-S., Lee, Y.S., Kim, Y.H. 2008. Identification and

Quantification of Anthocyanin Pigments in Colored Rice.Nutrition Research and Practice2 : 46-49

Kristamtini.,Taryono., P. Basunanda., R. H. Murtiand Supriyanta. 2012. Morphological Of Genetic Relationships Among Black Rice Landraces From Yogyakarta And Surrounding Areas. ARPN Journal of Agricultural and Biological Science. 1990-6145.

Kristamtini., Taryono., P. Basunandadan R.H. Murti.2013. KeragamanGenetikdanKorelasi Parameter Warna Beras dan Kandungan Antosianin Total Sebelas Kultivar Padi Beras Hitam Lokal. IlmuPertanian, 17(1), $2014: 57$ - 70 .

Lee, J.H. 2010. Identification and quantification of anthocyanins from the grains of black rice (Oryza sativa L.) Varieties. Food Sci. Biotechnol. 19(2): 391-397.

Lu, P., Weaver, V.M., Werb, Z. 2012. The extracellular matrix: A dynamic niche in cancer progression. Review. The Journal of Cell Biology, 196(4):395

Matsuba, Y., N.Sasaki, M, Tera, M. Okamura, Y. Abe, E. Okamoto,H. Nakamura, H.

Funabashi, M. Takatsu, M. Saito, H. Matsuok, K. Nagasawa, and Y. Ozek, 2010, A Novel Glucosylation Reaction on Anthocyanins Catalyzed by Acyl-Glucose-Dependent lucosyltransferase in the Petals of Carnation and Delphinium.

Meyer, B. N., Ferrigni, N. R., Putnam, J. E., Jacobsen, L. B., Nichols, D. E., McLaughlin, J. L. 1982. Brine Shrimp : A Convinient General Bioassay for Active 
Plant Constituent. Planta Med. 45 : 31 34.

Mohanlal, S., Parvathy, R., Shalini, V., Helen, A., Jayalekshmy, A. 2011. Isolation, characterisation and quantification of tricin and flavonolignans in the medicinal rice Njavara (Oryza sativa L.) ascompared to staple varieties. Plant Foods Hum Nutr 66:91-96

Nurhayati, A.P.D., Pratiwi, P., Wahyuono, S., Istriyati, Purnomo, H. and Syamsu. 2015. In Vitro Test and Molecular Docking of Alkaloid Compound in Marine Sponge Cinachyrella anomala against T47D Cell Cycle. J Marine Sci Res Dev, 5:2, 1-3

Pratiwi, R., Purwestri,Y.A. dan Tunjung. W.A.S., 2014. Efek Diet Pelet Nasi dari

Padi (Oryza sativa L.) "Cempo Ireng", "Cempo Abang", dan "IR-64" terhadap Profil Lipid Serum Darah Tikus Putih (Rattus norvegicus Berkenhout, 1769) Hiperlipidemia. Prosiding Seminar dan Workshop Nutrigenomik "Peran Makanan Fungsional dalam Penanganan Penyakit Degeneratif dengan Pendekatan Nutrigenomik".

Suliartini, N.W.S., G.R. Sadimantara, T. Wijayanto dan Muhidin. 2011. Pengujian Kadar Antosianin Padi Gogo Beras Merah Hasil Koleksi Plasma Nutfah Sulawesi Tenggara. Jurnal Ilmiah Crop Agr. (4) 2.

Sugimoto, K., Tamayose, K., Sasaki, M., Hayashi, K., Oshimi, K. 2002. Low-dose doxorubicin-induced necrosis in Jurkat cells and its acceleration and conversion to apoptosis by antioxidants. Br J Haematol. 118: 229-238.

Tanaka, Y., N. Sasaki, and A. Ohmiya, 2008, Biosynthesis of plant pigments: anthocyanins, betalains and carotenoids. Plant J. 54:733-749.

Xia X., W.L.J. Ma, M. Xia, M. Hou, Q. Wang and H. Zhu. 2006. An anthocyaninrich extract from black rice enhance atheroscleorotic plaque stabilization in apolipoprotein E-deficient mice. J. Nutr. 136: 2220-2226. 